\title{
(5)
}

\author{
AL-DZIKRA \\ Jurnal Studi Ilmu Al-Qur'an Dan Al-Hadits \\ http://ejournal.radenintan.ac.id/index.php/al-dzikra \\ Volume 12, No. 1, Juni Tahun 2018, Halaman 1 - 20 \\ DOI://dx.doi.org/10.24042/al-dzikra.v12i1.2927
}

\section{KAJIAN AL-QUR'AN DAN SAINS TENTANG KERUSAKAN LINGKUNGAN}

\author{
Eko Prayetno \\ Universitas Islam Negeri Sunan Kalijaga Yogyakarta \\ ekoprayetno124@gmail.com
}

\begin{abstract}
Abstrak
Salah satu faktor terjadinya kerusakan alam adalah hubungan yang tidak seimbang antara manusia dan alam itu sendiri. Oleh karena itu, perlu adanya pemahaman setiap manusia terhadap pesan-pesan dalam al-Qur'an terkait dengan pemeliharaan alam. Beberapa cara yang dapat digunakan dalam menyampaikan pesan al-Qur'an kepada manusia adalah melalui pendekatan teks dan kontekstual terhadap al-Qur'an. pendekatan kontekstual sangat dibutuhkan dalam mendukung pemahaman terhadap teks di dalam al-Qur'an. Pendekatan ini akan menggiring pemahaman kondisi ayat turun dengan kondisi yang tengah kita alami. Hasil yang dapat dicapai dengan pendekatan ini adalah manusia dapat mencocokkan pengambilan sikap sesuai dengan apa yang dikehendaki oleh ayat berdasarkan pemahaman sejarah turunnya ayat tersebut. sementara jika kita hanya terbatas teks maka kita akan cenderung memaksakan maksud ayat karena hanya terpaku terhadap lafal teks saja. dengan memahami keduanya maka kita akan dapat menghubungkan dengan kondisi saat ini, dimana ilmu sains juga berkembang bersamaan dengan agama. Implikasi yang dapat kita capai adalah menghubungkan pemngetahuan agama yang sakral dengan pengetahuan sains yang cendrung baru dan bersifat modern dalam artian pendukung.
\end{abstract}

Kata Kunci: al-Qur'an, Sains, Lingkungan. 


\section{A. Pendahuluan}

Salah satu fenomena yang menarik untuk dibicarakan adalah munculnya musibah atau serentetan musibah yang kemunculannya diduga-duga erat kaitannya dengan manusia. Baik dalam sisi teologis maupun sains menjelaskan adanya hubungan kausalitas antara manusia dan alam, tidak hanya itu melainkan terdapat adanya hubungan antara Tuhan, alam, dan manusia itu sendiri. Bencana yang terjadi seakan buah dari sebuah hubungan, baik itu hubungan antara Tuhan dengan alam, alam dengan manusia, manusia dengan tuhan, dan manusia dengan manusia. Musibah yang terjadi disini mengindikasikan kearah adanya musibah yang tidak berhubungan dengan manusia dan ada musibah yang berhubungan dengan manusia.

Artikel ini akan menjelaskan tentang gambaran secara keseluruhan dari musibah-musibah di atas. Dengan runtutan tema mulai dari pemahaman musibah di dalam al-Qur'an dengan metode pemahaman yang mendukung untuk mengkontekstualkan pesan alQur'an. Kemudian penjelasan sains yang berkenaan dengan musibah yang kerap melanda manusia serta bagaimana sikap manusia dalam menyikapi musibah yang ada. Karena tidak semua musibah atau bencana itu lahir dari ulah manusia, melainkan terdapat bencana yang sudah menjadi sunnatullah.

\section{B. Sekilas Tentang Memahami Al-Qur'an}

Memahami al-Qur'an adalah sebuah upaya yang dapat dilakukan untuk dapat memahami pesan yang terkandung di dalam al-Qur'an itu sendiri. Upaya ini dilakukan karena sesungguhnya manusia mempunyai peran dalam menentukan arah tujuan hidupnya. Sebagaimana yang difirmankan oleh Allah SWT dalam kalam-Nya QS. al-Ra'du [13]:11.

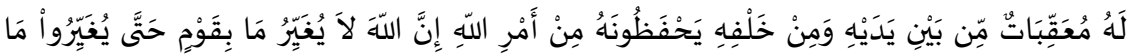

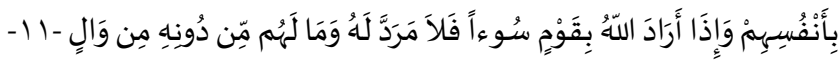

Baginya (manusia) ada malaikat-malaikat yang selalu menjaganya bergiliran, dari depan dan belakangnya. Mereka menjaganya atas perintah Allah. Sesungguhnya Allah tidak akan mengubah keadaan 
suatu kaum sebelum mereka mengubah keadaan diri mereka sendiri. Dan apabila Allah Menghendaki keburukan terhadap suatu kaum, maka tak ada yang dapat menolaknya dan tidak ada pelindung bagi mereka selain Dia.

Dalam menentukan arah tujuan hidupnya, manusia dapat mengambil pelajaran dari apa yang terdapat di dalam al-Qur'an. Menurut Gusliyani, di dalam al-Qur'an terdapat konsep ilmu yang secara mutlak muncul dalam maknanya yang umum, dan beberapa ayat al-Qur'an secara eksplisit menunjukan bahwa ilmu itu tidak hanya berupa prinsip-prinsip dan hukum-hukum agama saja. ${ }^{1}$ Dalam point pertama yang ditawarkan oleh Gusliyani terdapat adanya ayat al-Qur'an yang peruntukannya itu tidak hanya diberikan kepada umat Islam melainkan non-Islam pun juga berhak menerimanya. Sama halnya dengan perbedaan antara lafal " $y \bar{a}$ ayyuhalażina àmanū" dengan lafal "yā ayyuhannās", dimana lafal "yā ayyuhalażina āmanū" peruntukan pesan yang terkandung di dalam al-Qur'an hanya diperuntukan untuk orang muslim, sedangkan dalam penggalan lafal ayat " $y \bar{a}$ ayyuhannās" peruntukan pesan yang terkandung di dalamnya tidak hanya diberikan kepada muslim melainkan para non muslim juga berhak mengambil pelajaran di dalanya.

Dalam point yang kedua dapat dipahami bahwa terdapat pesan yang terkandung di dalam al-Qur'an yang bersifat menyeluruh, tidak hanya berputar dalam persoalan agama, melainkan di dalamnya juga terdapat ilmu pengetahuan. Dengan mampunya manusia mengambil pesan di dalam al-Qur'an berupa ilmu pengetahuan itu manusia dapat menjalankan tanggung jawabnya yaitu khalifah Allah SWT di atas muka bumi, karena bumi dan langit beserta isinya telah Allah SWT tundukkan bagi kepentingan manusia, tinggal bagimana manusia memanfaatkan alam semesta ini dengan pengetahuan yang dimilikinya.

Kemudian Terdapat beberapa alasan yang menjadikan seorang muslim itu penting untuk memahami al-Qur'an, yaitu:

${ }^{1}$ Jamal Fakhri, Sains Dan Teknologi Dalam Al-Qur'an Dan Impliksinya Dalam Pembelajaran, dalam jurnal Ta'dib, vol. XV No. 01, Edisi. Juni 2010, 122-142 


\section{Al-Qur'an Sumber Kesejahteraan}

Sebuah titik yang ingin penulis capai dalam sub-tema ini adalah titik kesejahteraan. Salah satu jalan yang dapat ditempuh untuk mencapai kesejahteraan adalah dengan memahami ilmu pengetahuan. Menurut Fazlur Rahman, terdapat beberapa kelompok pendapat mengenai al-Qur'an, yaitu: pertama, mereka yang berpendapat bahwa al-Qur'an ibarat kitab undang-undang yang telah lengkap pasal demi pasal yang melingkupi seluruh aspek kehidupan manusia baik politik, ekonomi, moral, budaya, maupun ilmu pengetahuan. Kedua, al-Qur'an adalah landasan religius seluruh aspek kehidupan. Dengan demikian al-Quran merupakan inspirasi kehidupan yang mengarah kepada kebenaran dan kebaikan, memberikan ide moral pada seluruh aspek kehidupan manusia. $^{2}$

Dari dua point tersebut terdapat point penting yang ingin penulis garis bawahi yaitu al-Qur'an sebagai sumber lengkap ilmu pengetahuan dan landasan religius seluruh aspek kehidupan yang berupa ide moral, dari dua point ini dirasa terjaganya alam dapat diwujudkan dengan adanya ilmu pengetahuan yang didasari landasan religius dalam kehidupan karena adanya penanaman nilai moral di dalamnya. Saat ini dapat kita lihat betapa banyaknya orang yang berilmu akan tetapi tidak mempunyai landasan religius yang kuat dalam dirinya, sehingga dengan tidak adanya landasan religius di dalam diri seseorang maka tidak ada alat yang menjadi pengukur atau pengontrol perbuatannya, atau bisa dikatakan bahwa orang tersebut bebas berbuat tanpa ada batasan dalam ilmu pengetahuan. Hal seperti ini dinilai tidak baik karena kerusakan sebuah alam dapat dipicu dengan adanya ilmu pengetahuan yang tidak ada pengontrol kesadaran berupa nilai moral. Hal ini bisa saja memicu pada eksploitasi alam dan merusak lingkungan karena ilmu pengetahuan yang tidak dapat dipertanggung jawabkan.

${ }^{2}$ Mustaqimah, urgensi tafsir kontekstual dalam penafsiran al-Qur'an, journal IANgorontalo vol. 12 no. 1 juni 2015, 138-149 


\section{Ragam Penafsiran}

Beragam penafsiran adalah salah satu cara untuk memahami al-Qur'an. Akan tetapi, dalam penafsiran terdapat ragam teori yang digunakan seperti pendekatan tekstual dan pendekatan kontekstual yang akan menghasilkan pemahaman yang berbeda terhadap sumber hukum Islam itu sendiri yaitu al-Qur'an dan Hadits. ${ }^{3}$ Oleh karena itu penting bagi kita untuk memahami kondisi dimana kita berada karena disinilah kita bisa memasukkan tafsir melalui pendekatan kontekstual. Kata tafsir yang penulis maksud dalam tulisan ini adalah tidak sebatas pada ayat yang belum jelas maknanya saja, melainkan penulis bermaksud menegaskan lafal ayat yang sudah jelas secara makna untuk dapat dihubungkan dengan upaya menjaga alam.

Menurut M. Amin Abdullah, tafsir dikenal sebagai cara mengurai bahasa, konteks, dan pesan-pesan moral yang terkandung dalam teks atau nash kitab suci. Dari pendapat M. Amin Abdullah tersebut penulis ingin menekankan pemahaman pesan-pesan moral yang terkandung di dalam al-Qur'an. Maka untuk dapat mengurai pesan tersebut diperlukan beberapa metode dan pendekatan. Metode tafsir yang masyhur antara lain yaitu: metode tafsir tahlili (analitis), metode tafsir maudhu'i (tematik), metode tafsir muqaran (komparatif), dan metode tafsir ijmali (global). Sedangkan pendekatannya, antara lain pendekatan objektif dan subjektif, pendekatan langsung dan tidak langsung, pendekatan komprehensif dan sektoral, pendekatan disipliner, multi disipliner, dan interdisipliner serta pendekatan tekstual dan kontekstual. Demikian dalam makalah ini akan dibahas mengenai ragam teori penafsiran Al-Qur'an dengan pendekatan tekstual dan kontekstual. ${ }^{4}$

3. Mamahami Al-Qur'an Adalah Kewajiban Seorang Muslim

Memahami nilai-nilai yang terkandung di dalam al-Quran adalah salah satu tanggung jawab bagi seorang muslim terhadap alQuran selain membaca, mempelajari dan mengamalkan nilai-nilai

${ }^{3} \mathrm{Ibid}$

${ }^{4}$ Ibid 
di dalam al-Qur'an. Al-Qur'an adalah wahyu yang turun kepada Nabi Muhammad SAW, kandungan al-Qur'an tidak dapat difahami dengan tepat melainkan dengan pemahaman yang diajarkan oleh Nabi Muhammad SAW kepada sahabat-sahabat beliau. ${ }^{5}$ Dalam memahami ayat al-Qur'an pun para sahabat Nabi Muhammad SAW juga sempat mengalami kebingungan setelah wafatnya Nabi Muhammad SAW karena tidak ada petunjuk langsung dari nabi, terlebih jika kondisi hal yang dialami itu tidak persis seperti yang ditemukan semasa Nabi Muhammad SAW masih hidup mendampingi para sahabat. Seperti yang dilakukan 'Umar bin Khattab ketika dia berusaha untuk memperhatikan tujuan utama dari syariat dengan berusaha menafsirkan sebuah ayat dengan ayat lain dalam al-Qur'an terkait dengan siapa saja yang berhak menerima rampasan perang. ${ }^{6}$

Dari peristiwa 'Umar bin Khattab tersebut disebutkan bahwa terdapat orang yang tidak sepaham dengan 'Umar dengan melaporkan kejadian itu kepada keponakan Nabi Muhammad yang dikenal luas ilmunya dan memahami al-Qur'an dengan pasti yaitu 'Ali bin Abi Thalib. Dari sini tampak bahwa pemahaman terhadap al-Qur'an memang dibutuhkan pemahaman yang luas yaitu pemahaman yang tidak hanya terikat pada aspek teks melainkan juga perlu memperhatikan pada aspek konteks. Salah satu tujuannya adalah menghindari madharat berupa perpecahan dengan mengutamakan kemaslahatan berupa persatuan. Maka salah satu upaya yang dapat dilakukan dalam memahami nilai-nilai yang terkandung di dalam al-Qur'an adalah dengan menggiring pemahaman dengan melihat situasi dimana kita berada dalam sebuah kondisi sekarang. Istilah melihat situasi dimana kita berada dapat dikonotasikan dengan kata "kontekstualisasi" atau "reaktualisasi".

Secara umum kontekstualisai dan reaktualisasi adalah sebuah istilah yang intinya sama yaitu, mengaktualkan kembali

${ }^{5}$ Mohd Riduan Khairi, Tanggung Jawab Terhadap al-Quran, dalam https://encikriduan.wordpress.com 2015), 68-69

${ }^{6}$ Tasaro GK, Muhammad Sang Pewaris Hujan, (Yogyakarta: Bentang, 
sesuatu baik itu pemikiran atau yang lainnya ke dalam konteks sekarang, yang mampu membuat ajaran itu menjadi relevan di masa sekarang. ${ }^{7}$ Untuk mendapatkan sebuah pengaktualan sebuah konteks maka diperlukan adanya sebuah pendekatan, yaitu pendekatan kontekstual. Kata "kontekstual" berasal dari "konteks" yang dalam Kamus Besar Bahasa Indonesia mengandung dua arti: Pertama, bagian suatu uraian atau kalimat yang dapat mendukung atau menambah kejelasan makna; kedua, situasi yang ada hubungan dengan suatu kejadian. ${ }^{8}$

Dari sini pemahaman kontekstual atas al-Qur'an adalah memahami makna ayat-ayat al-Qur'an dengan memperhatikan dan mengkaji keterkaitannya dengan peristiwa atau situasi yang melatarbelakangi turunnya ayat-ayat tersebut, atau dengan kata lain, dengan memperhatikan dan mengkaji berdasarkan konteks. Dengan demikian, pemahaman kontekstual atas ayat-ayat Al-Qur'an berarti memahami al-Qur'an berdasarkan kaitannya dengan peristiwaperistiwa dan situasi ketika ayat-ayat diturunkan, dan kepada siapa serta tujuannya apa ayat tersebut diturunkan. Untuk itulah al-Qur'an berusaha didialogkan dengan realita zaman sekarang, melalui studi kontekstualitas al-Qur'an.

Sedangkan makna yang labih luas lagi, studi tentang kontekstual al-Qur'an adalah studi tentang peradaban yang didasarkan pada pendekatan sosio-historis. Adapun pemahaman sosio-historis dalam pendekatan kontekstual adalah pendekatan yang menekankan pentingnya memahami kondisi-kondisi aktual ketika al-Qur'an diturunkan dalam rangka menafsirkan pernyataan legal dan sosial ekonominya. Atau dengan kata lain, memahami alQur'an dalam konteks kesejarahan dan harfiyah, lalu memproyeksikannya kepada situasi masa kini kemudian membawa fenomena-fenomena sosial ke dalam naungan-naungan tujuan alQur'an. Aplikasi pendekatan kesejarahan ini menekankan pentingya perbedaan antara tujuan atau "ideal moral" al-Qur'an dengan

${ }^{7}$ Muhammad Alfatih Suryadilaga, Kontekstualisasi Hadis Dalam Kehidupan Berbangsa Dan Berbudaya, (Yogyakarta: Kalam, 2017), 217

${ }^{8}$ Mustaqimah, Urgensi Tafsir Kontekstual dalam Penafsiran Al-Qur'an, journal IANgorontalo vol. 12 no. 1 juni 2015, 138-149 
ketentuan legal spesifiknya dan menekankan pentingnya membedakan antara aspek legal (bungkus) dan aspek etik (jiwa). Ideal moral yang dituju al-Qur'an lebih pantas diterapkan ketimbang ketentuan legal spesifiknya.

Upaya pemahaman alqur'an dengan metode ini dapat dilakukan karena Allah SWT tidak membebankan kepada hambanya dengan sesuatu perkara yang sukar. Sesungguhnya Allah SWT telah berfirman dalam Q. S. al-Qamar [54]:17

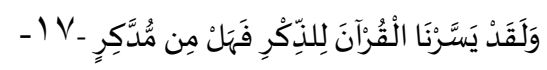

Dan sungguh, telah Kami Mudahkan al-Quran untuk peringatan, maka adakah orang yang mau mengambil pelajaran?

Kemudian imam syafi'i juga berpesan bahwa "Barang siapa yang belajar al-Qur'an, maka harga dirinya akan mulia”. Untuk mencapai kemulian dengan cara memahami al-Qur'an sarjana Islam yaitu syaikh Muhammad Jamil Zainu, dia menulis beberapa tahapan dalam memahami al-Qur'an yaitu: ${ }^{9}$

a. Memahami ayat al-Quran dengan ayat al-Qur'an yang lain.

b. Memahami ayat al-Qur'an dengan memahami hadits Nabi Muhammad SAW. Hal ini penting karena Rasulullah SAW yang paling tahu apa yang dimaksudkan oleh Allah SWT

c. Memahami ayat al-Qur'an dengan penjelasan sahabat. ${ }^{10}$ Karena mereka adalah orang-orang yang selalu menemani Rasulullah SAW dan banyak belajar dari baliau.

d. Memahami ayat al-Qur'an dengan penjelasan tabi' in. ${ }^{11}$ Hal ini penting karena adlanya ketersambungan periwayatan yaitu tabi'in yang bertemu dengan sahabat dan sahabat bertemu dengan Rasulullah SAW.

Zainu

${ }^{9}$ lihat Bagaimana Memahami al-Qur'an karangan Muhammad Jamil

${ }^{10}$ Antara sahabat Nabi Muhammad SAW yang terkenal dengan membuat banyak penjelasan ayat al-Qur'an ialah sahabat Ali bin Abi Thalib, Abdullah bin Mas'ud, Abdullah bin Abbas.

${ }^{11}$ Mujahid, 'Ikrimah, Atha bin Abi Robah, dan Said bin Jubayr. 
e. Menafsrikan al-Qur'an dengan perkataan bahasa Arab. Dengan mengetahui dan memahami kaidah bahasa Arab yang benar, maka akan menghasilkan penafsiran yang benar pula.

f. Mengetahui istimbath, yaitu pemahaman yang mendalam dalam mengambil kesimpulan dari satu ayat.

g. Mengetahui asbabun nuzul yaitu mengetahui latar belakang sebab-sebab turunnya ayat sangat membantu dalam memahami al-Qur'an

h. Mengetahui Nasikh dan Mansukh. Nasikh adalah mengahapus hukum dan menggantikannya dengan dalil syar'i yang datang kemudian mansukh adalah hukum yang diangkat atau dihapus.

i. Pengetahuan tentang ayat-ayat Makkiyah dan Madaniyah. Ayat Makkiyah adalah wahyu yang diturunkan kepada rasul sebelum hijrah, walaupun diturunkannya bukan di Mekkah, sedangkan ayat Madaniyyah adalah wahyu yang diturunkan setelah hijrah, walaupun turunnya di Mekkah.

Bagi Masyarakat Indonesia memahami ayat al-Quran terbantu dengan adanya terjemahan-terjemahan kitab tafsir, seperti tafsir al-Qur'āanul 'Ażim karangan Ibn Katsir yang kemudian dikenal dengan tafsir Ibn Katsir. Tafsir Taysirū al-Karìm Rahmān fì Tafsìr Kalām al-Manāan karangan Syaikh Abdurrahman bin Nassir as-Sa'di. Kitab Adwa'ul Bayan karangan 'Ilamah Muhammad asySyinqithi. Kitab Tafsir al-Aisar karangan Syaikh Abu Bakar Jabir al-Jazairi. Kitab tafsir al-Azhar karangan Buya Hamka. Dan Kitab tafsir al-Misbah karangan Prof. Dr. Quraisy Shihab.

\section{Sekilas Tentang Menjaga Alam}

Alam adalah sebuah medan yang telah Tuhan ciptakan sebagai tempat manusia untuk hidup. Kemudian bagaimana manusia memperoleh kenyamanan yang didapat dari alam itu adalah tergantung pada usaha manusia itu sendiri dalam memanfaatkan alam, karena berubahnya sebuah alam ke arah yang tidak menguntungkan atau biasa kita sebut dengan bencana itu dipengaruhi dua hal, yaitu akibat bencana yang memang telah Tuhan takdirkan dan bencana yang muncul akibat ulah tangan manusia sendiri. Terdapat empat konsep penting yang harus 
dipahami untuk membangun pemahaman agama (Islam) terhadap ekologi atau lingkungan yaitu taskhir (penundukan), 'abd (kehambaan), khalifah (pemimpin) dan amanah (dipercaya). Keempatnya berasal dari konsep tujuan penciptaan alam semesta dan manusia.

Pandangan yang komprehensif terhadap empat konsep di atas dengan seimbang akan memberikan pandangan yang baik mengenai relasi manusia dan lingkungan dalam kaitannya dengan keseimbangan alam. ${ }^{12}$ Yang dimaksud lingkungan atau alam disini adalah segala sesuatu yang berada di sekitar manusia, baik binatang, tumbuh-tumbuhan, maupun benda-benda tak bernyawa. Pada dasarnya, akhlak yang diajarkan Al-Quran terhadap lingkungan bersumber dari fungsi manusia sebagai khalifah. Sebagaimana firman Allah SWT dalam Q. S. al-Baqarah [2]: 30

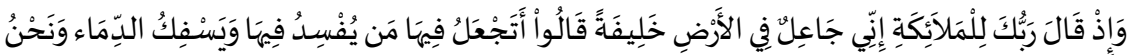

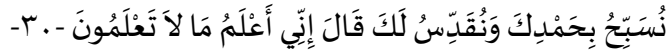

"Dan (ingatlah) ketika Tuhan-mu Berfirman kepada para malaikat, "Aku hendak menjadikan khalifah di bumi." Mereka berkata, "Apakah Engkau hendak menjadikan orang yang merusak dan menumpahkan darah di sana, sedangkan kami bertasbih memuji-Mu dan menyucikan nama-Mu?" Dia Berfirman, "Sungguh, Aku Mengetahui apa yang tidak kamu ketahui."

Kekhalifahan menuntut adanya interaksi antara manusia dengan sesamanya dan manusia terhadap alam. Manusia merupakan bagian dari alam semesta (kosmos) yang telah diciptakan oleh Allah SWT dan sebagai abdi-Nya. Manusia diberikan kuasa oleh Tuhan untuk memanfaatkan, mengolah, dan menjaga potensi alam semesta yang telah diciptakan-Nya (khalifatullah). Dengan alam pula manusia berproses dan memperoleh pengetahuan dari Tuhan. Oleh karena itu membahas hubungan antara manusia, alam, dan Allah SWT sebagai pencipta tidak dapat dipisahkan. ${ }^{13}$

${ }^{12}$ Drs. Misbahkhunur, M.Si., Tanggung Jawab Terhadap Alam Dan Lingkungan, modul 8 universitas brawijaya, h. 221-240

${ }^{13}$ Samidi, Tuhan, Manusia, Dan Alam: Analisis Kitab Primbon Atassadhur Adammakna, dalam Shahih vol. 1, No. 1, Januari-Juni 2016, h. 14-26 
Kekhalifahan mengandung arti pengayoman, pemeliharaan serta pembimbingan agar setiap makhluk mencapai tujuan penciptaannya. Tujuan Allah mensyariatkan hukumnya adalah untuk memelihara kemaslahatan manusia, sekaligus untuk menghindari kerusakan (mafsadah), baik di dunia maupun di akhirat. Semua makhluk hidup di planet bumi ini sangat bergantung pada lingkungannya, tidak terkecuali manusia. Hubungan simbiosis (saling ketergantungan) antara manusia dengan lingkungan di sekitarnya sangat menentukan kesinambungan antar keduanya.

Dengan kata lain, kelangsungan hidup (manusia dan alam) sangat tergantung ada sikap dan perilaku manusia sebagai khāalifah fì al-Arḍ (subjek atau pengelola) bumi. Walaupun sebagai subjek terhadap alam, manusia tidak serta merta dapat memperlakukan alam sekehendaknya. Alam dengan lingkungannya akan melakukan reaksi (perlawanan) terhadap manusia yang mengakibatkan kepunahan umat manusia di bumi. Peran manusia sebagai subjek atas alam tidak mengurangi keharusan manusia dalam kebergantungannya pada lingkungan. Ini artinya, melestarikan lingkungan sama nilainya dengan memelihara kelangsungan hidup manusia dan segala yang eksis di alam. Sebaliknya, merusak lingkungan hidup dengan bentuk apapun merupakan bumerang yang serius bagi kelangsungan kehidupan di alam dengan segala isinya ini, termasuk manusia.

\section{Macam bentuk bencana pada alam}

Merujuk pada Undang-Undang No. 24 Tahun 2007 bencana alam adalah sebuah peristiwa atau serangkaian peristiwa yang mengancam dan mengganggu kehidupan dan penghidupan masyarakat yang disebabkan, baik oleh faktor alam dan atau nonalam maupun faktor manusia, kerusakan lingkungan, kerugian harta benda, dan dampak psikologis. ${ }^{14}$ Dari pengertian ini kita dapat menggiring pengetahuan kita terkait bencana alam bahwa penyebab bencana alam terbagi menjadi tiga point penting yaitu: pertama,

\footnotetext{
${ }^{14} \mathrm{BNPD}$, pengetahuan defenisi dan jenis bencana, dalam http://www.bnpd.go.id/
} 
bencana yang disebabkan oleh alam sendiri maksudnya adalah bencana yang penyebab timbulnya tidak dipengaruhi oleh ulah tangan manusia seperti gempa bumi, tsunami, kekeringan, angin topan, dan lain sebagainya. Kedua, bencana non alam maksudnya adalah bencana yang diakibatkan oleh sebuah peristiwa atau serangkaian peristiwa non alam yang antara lain berupa gagal teknologi, gagal modernisasi, epidemi, wabah penyakit, kecelakaan transportasi, kecelakaan industri, dan kejadian luar biasa. Ketiga, bencana sosial maksudnya adalah bencana yang diakibatkan oleh sebuah peristiwa atau serangkaian peristiwa yang diakibatkan oleh manusia yang meliputi konflik sosial antar kelompok atau antar komunitas masyarakat, teror, sabotase, dan SARA.

Sedangkan dalam terminologi Islam, bencana diistilahkan dengan beberapa redaksi. Diantaranya yang paling mendasar maknanya adalah al-Baliyyah dan atau al-Dahr yang berarti perkara yang dibenci manusia, semisal kemalangan, musibah dan lainlain. ${ }^{15}$ Bencana disini mempunyai beberapa sifat yaitu bencana yang bersifat hissī (inderawi) dimana akan banyak orang yang mampu melihat serta merasakannya dan ada bencana yang bersifat $r u h \bar{\imath}$ atau ma'nawī (rohani) yang jelas bencana seperti ini lebih mengarah kepada hal yang subjektif dimana hanya satu orang individu yang mengalami dan yang dapat merasakan serta menilainya, bencana dalam sifat ini diantaranya adalah tercabut atau berkurangnya iman dari dalam diri seseorang, ilmu yang tidak diamalkan dan sebagainya.

Sebelum berbicara mengenai bencana alam secara menyeluruh, ada baiknya dikaji terlebih dahulu bencana yang pernah terjadi dan disebutkan di dalam al-Qur'an.

1. Bentuk bencana alam di dalam al-Qur'an

Al-Qur'an dengan sangat jelas menguraikan bencana yang terjadi pada manusia, baik yang berhubungan dengan manusia itu sendiri, maupun yang terjadi di alam sekitar manusia. Secara umum,

${ }^{15}$ Muhammad Alfatih Suryadilaga, Pemahaman Hadits Tentang Bencana (Sebuah Kajian Teologis Terhadap Hadits-Hadits Tentang Bencana), dalam essensia Vol. XIV No. 1 April 2013, 83-102 
bencana yang disebutkan di dalam al-Qur'an terabagi menjadi dua point besar yaitu: ${ }^{16}$ Pertama, bencana yang semata-mata yang kejadiannya ditentukan oleh Allah SWT dan tidak terkait dengan selain-Nya, yaitu makhluk-Nya. Jadi, jenis bencana yang seperti ini mutlak dari Allah SWT atau dapat dikatakan sebagai Sunnatullah terhadap alam ini yang tidak dapat dirubah sesuai dengan ketentuan yang telah Allah SWT berikan atau tetapkan terhadap alam ini. Contoh dari sunnatullah seperti Matahari yang terbit dari arah Timur dan terbenam di arah Barat. Dan kedua tempat ini memang telah Allah pelihara. Sebagaimana firman-Nya dalam Q. S. ar-Rahman [55]:17

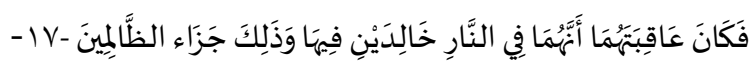

"Tuhan (yang Memelihara) dua timur dan Tuhan (yang Memelihara) dua barat".

Contoh sunnatullah lainnya adalah kematian manusia. Kita tidak bisa meminta kepada Allah SWT agar tidak bisa mati. Akan tetapi kamu boleh meminta umur yang panjang tentunya dengan tuntunan yang telah dijelaskan oleh Rasulullah SAW, seperti menyambung tali silaturahmi, baik dalam pandangan hadits ataupun penelitian. Dalam pandangan hadits disebutkan bahwa Rasulullah SAW pernah bersabda:

Barang siapa yang ingin dilapangkan rezekinya, dan ingin dipajangkn umurnya, maka hendaknlah ia menyambung silaturahmi. ${ }^{17}$

kemudian dalam pembuktian ilmiah juga telah dibuktikan bahwa silaturahmi dapat memperpanjang umur karena telah dibuktikan dengan kajian ilmiah yang menjelaskan bahwa dengan adanya silaturahmi maka terdapat kemungkinan besar terpecahnya suatu masalah seseorang dengan cara sharing pengalaman dalam silaturahmi, hal ini tentu akan mengurangi tingkat stres seseorang, dimana stres juga merupakan pemicu dari penyakit-penyakit yang mematikan bagi manusia, misalnya serangan jantung, kanker,

${ }^{16}$ Ibid.

${ }^{17}$ H.R. Muslim No. 4693 
obesitas, asma atau gangguan pernapasan, dan sebagainya. Hal seperti ini mungkin terjadi karena meminta umur yang panjang adalah termasuk ke dalam ranah kesangupan Allah SWT (Masyīatullah). Sebagaimana disebutkan dalam firman Allah SWTQ. S. al-Hadid [57]: 22 berikut:

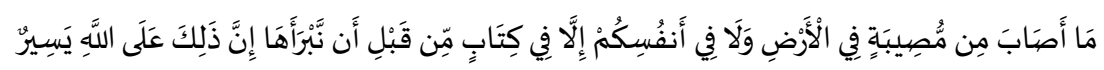

"Setiap bencana yang menimpa di bumi dan yang menimpa dirimu sendiri, semuanya telah tertulis dalam Kitab (Lauh Mahfudzh) sebelum Kami Mewujudkannya. Sungguh, yang demikian itu mudah bagi Allah".

Kedua, bencana yang ada sangkut pautnya dengan ulah tangan manusia. Disini terdapat hubungan sebab akibat antara tingkah laku manusia dengan bencana alam yang terjadi dalam sebuah lingkungan. Bencana yang ada hubungannya dengan tingkah laku manusia itu dapat berupa bencana di dalam tatanan sosial masyarakat, seperti: perang, konflik, kerusuhan, dan sebagainya. Serta ada pula yang berupa bencana yang terjadi di alam yaitu di sekitar lingkungan kita berada, misalnya adalah banjir, tanah longsor, dan sebagainya. Seperti yang diterangkan di dalam firman Allah SWTQ. S. asy-Syura [42]:30 berikut ini.

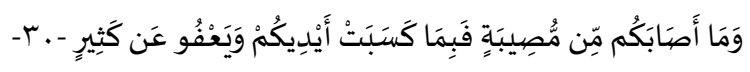

"Dan musibah apa pun yang menimpa kamu adalah karena perbuatan tanganmu sendiri, dan Allah Memaafkan banyak (dari kesalahankesalahanmu)".

Ayat di atas menyebutkan bahwa bencana atau musibah yang terjadi atau menimpa manusia adalah karena disebabkan oleh ulah tangan manusia itu sendiri. Merujuk pada ayat al-Qur'an di atas dijelaskan beberapa tingkah laku manusia yang dapat merusak atau memicu adanya bencana pada alam menjadi beberapa jenis, yaitu:

a. Ulah manusia secara fisik. Seperti yang difirmankan oleh Allah SWT dalam kalamnyaQ. S. ar-Ruum [30]:41 berikut ini:

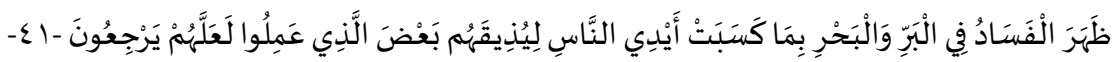

"Telah tampak kerusakan di darat dan dilaut disebabkan karena perbuatan tangan manusia; Allah Menghendaki agar mereka 
merasakan sebagian dari (akibat) perbuatan mereka, agar mereka kembali (ke jalan yang benar)".

Ayat di atas menjelaskan bahwa rusaknya alam atau terjadinya sebuah bencana alam terdapat hubungannya dengan apa yang dilakukan oleh manusia. Abul 'Aliyah berkata: "Barang siapa yang berlaku maksiat kepada Allah SWT di muka bumi, maka berarti dia telah berbuat kerusakan di dalamnya. Karena kebaikan bumi dan langit adalah dengan sebab ketaatan." 18

Pendapat ini mengindikasikan kepada adanya kerusakan yang muncul yang dikarenakan oleh perbuatan ulah tangan manusia yang mendasari perbuatannya dengan ketidaktaatan kepada Allah SWT. Contoh lazim yang sering kita jumpai adalah kerusakan pada hutan akibat ulah tangan manusia seperti melakukan penebangan pohon secara liar atau pembukaan lahan pertanian secara brutal yang mengakibatkan bencana lain muncul seperti tanah longsor, banjir, dan lain sebagainya.

b. Tingkah laku manusia yang melampaui batas norma agama dan norma kemanusiaan. Seperti yang difirmankan oleh Allah SWT dan kalam-Nya Q. S. al-Isra'[17]:16berikut ini.

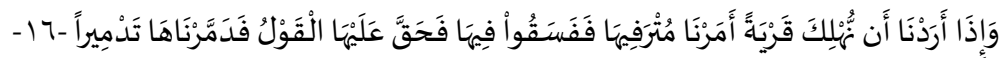

"Dan jika Kami Hendak membinasakan suatu negeri, maka Kami Perintahkan kepada orang yang hidup mewah di negeri itu (agar menaati Allah), tetapi bila mereka melakukan kedurhakaan di dalam (negeri) itu, maka sepantasnya berlakulah terhadapnya perkataan (hukuman Kami), kemudian Kami Binasakan sama sekali (negeri itu)".

Sesungguhnya Allah SWT tidaklah menghendaki perbuatan yang berlebihan pada manusia, terlebih pada perbuatan yang buruk. Dalam ayat ini dijelaskan Allah SWT akan memenuhi apa yang diminta oleh manusia seperti untuk hidup mewah atau menjadi seorang pemimpin dalam arti untuk memanfaatkan kekayaan alam dengan semaksimal mungkin.

${ }^{18}$ M. Abdul Ghoffar E.M, Tafsir Ibnu Katsir jilid 6, ( Bogor: Pustaka Imam Syafi'i, 20014), 380 
Akan tetapi Allah SWT tidak menghendaki perbuatan yang melampaui batas. Hal yang demikian Allah SWT anjurkan agar tidak membuat manusia lupa diri yang kemudian melakukan hal yang berlebihan yang justru membuat manusia durhaka dengan apa yang dicapainya tersebut. sesungguhnya Allah SWT tidak memerintahkan manusia untuk berbuat keji, melainkan Allah SWT memerintahkan manusia untuk berbuat ketaatan. Allah akan memberikan berupa kebinasaan kepada manusia apabila manusia justru mengerjakan perbuatan yang keji dan berlebihan yang indikasinya mengarahkan manusia kepada sifat kefasikan seperti Ayah membunuh anak, Anak membunuh ayah, Istri memperlakukan suami dengan tidak lazim, kebohongan dan lain sebagainya. Ketika kerusakan yang demikian telah dilakukan oleh manusia maka Allah SWT akan menjatuhkan keputusan-Nya berupa kebinasaan atau azab dalam suatu negeri. Seperti yang digambarkan dalam Q. S. anNahl [16]:112 bahwa:

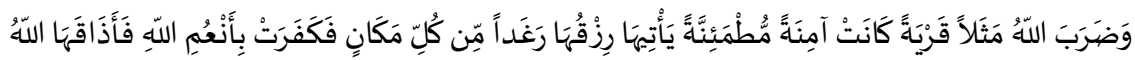

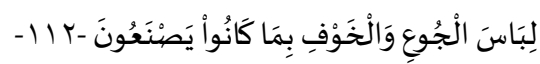

"Dan Allah telah Membuat suatu perumpamaan (dengan) sebuah negeri yang dahulunya aman lagi tenteram, rezeki datang kepadanya melimpah ruah dari segenap tempat, tetapi (penduduk)nya mengingkari nikmat-nikmat Allah, karena itu Allah Menimpakan kepada mereka bencana kelaparan dan ketakutan, disebabkan apa yang mereka perbuat."

Di dalam ayat ini dijelaskan bagaimana penduduk di kota Mekkah. Sebelumnya Makkah merupakan kota yang aman, nyaman, dan penuh ketentraman dimana orang-orang yang hidup disekitarnya banyak yang tergiur untuk tinggal di sana. Barang siapa memasukinya, maka dia akan aman, dan tidak akan takut. Adanya limpahan rezeki yang banyak lagi disertai kemudahan untuk mendapatkannya. Sampai pada kemudian mereka mengingkari kenikmatan yang ada yaitu diutusnya nabi di kalangan mereka yaitu Nabi Muhammad SAW. 
Oleh karena itu Allah SWT mengganti keadaan mereka dengan keadaan yang lain yaitu Allah SWT memakaikan dan membuat mereka merasakan kelaparan kepada penduduk Mekkah, setelah sebelumnya mereka memperoleh berbagai jenis buah-buahan dan rizkinya datang dengan melimpah ruah dari segenap penjuru kota. Yang demikian itu terjadi karena mereka mendustai kenikmatan yang telah dihadirkan kepada mereka yaitu adanya nabi dari kalangan mereka yaitu Nabi Muhammad SAW dan bahkan mereka menentang dengan keras apa yang dibawa oleh Nabi utusan Allah SWT untuk tanah Arab tersebut. Kemudian beliau mendoakan keburukan terhadap mereka berupa kekurangan pangan selama tujuh tahun seperti yang menimpa kaum Nabi Yusuf AS. Mereka ditimpa dengan kekeringan yang melenyapkan segala sesuatu, sehingga mereka memakan kotoran unta yang dicampur dengan darahnya jika mereka menyembelihnya. Kemudian adanya rasa takut yang melanda mereka, yang demikian itu berlaku karena mereka telah mengganti rasa aman dengan rasa takut kepada Rasulullah SAW dan para Sahabatnya ketika mereka telah berhijrah ke madinah, yaitu rasa takut akan kekuatan yang dimiliki oleh Rasulullah SAW dengan pasukan dan bala tentaranya. Allah SWT menghancurkan dan menghinakan segala sesuatu yang mereka miliki, sehingga Allah SWt bebaskan kota Mekkah untuk Rasulullah melalui berhasilnya Fathul Mekkah yang Rasulullah lakukan dengan mengalahkan ulah para kaum kafir Quraisy seperti kezhaliman, dan pendustaan mereka terhadap risalah yang dibawa oleh Rasulullah SAW padahal adanya nabi ini Allah SWT angkat dari kalangan mereka sendiri. ${ }^{19}$

Dari uraian ayat di atas maka dapat kita tarik kesimpulan bahwa Allah SWT maha membalikkan keadaan, sebagaimana Allah SWT telah membalikkan kondisi kaum kafir dari yang dulunya aman menjadi takut dan dari yang dulunya dilimpahkan rezeki kepada mereka menjadi kelaparan serba kekurangan. Maka demikian pula Allah membalikkan

\footnotetext{
${ }^{19}$ M. Abdul Ghoffar E.M, Tafsir Ibnu Katsir jilid 5, ( Bogor: Pustaka Imam Syafi'i, 20014), 114
} 
keadan orang-orang mukmin dari rasa takut menjadi rasa aman dan dari rasa kekurangan menjadi mendapat banyak limpahan rezeki. Tercatat dalam sejarah bahwa orang yang beriman dan tidak melampaui batas akan mendapatkan perlindungan dari Allah SWT seperti adanya bimbingan langsung dari Allah SWT dalam menjalankan kehidupan, misalnya kisah 'Umar bin Khattab yang menjadi Amirul Mukmini setelah wafatnya khalifah pengganti Nabi Muhammad SAW yaitu Abu Bakr Ash-Shidiq. Ketika 'Umar bin Khattab memimpin kota Madinah banyak kemajuan yang didapatkan oleh para kaum muslimin diantaranya adalah kenyaman tinggal di kota Nabi tersebut, dikatakan bahwa begitu nyamannya kota tersebut di bawah kepemimpan sang Amirul Mukminin mengundang minat orang yang bukan penduduk asli madinah untuk menetap di kota tersebut atau sekadar di sekitarnya.

Perlu diketahui bahwa turunnya sebuah musibah dapat diartikan kepada siapa musibah itu turun. Bencana yang terdapat di dalam al-Qur'an setidaknya memiliki dua fungsi berdasarkan pemaparan di atas. Adapun fungsi yang pertama dapat kita lihat dari sudut pandang orang kafir yang menerimanya, jika kita memandang orang kafir yang menerimanya musibah disana dapat diartikan sebagai peringatan (al-nakāl) dan hukuman (al-'uqūbah) atau dalam terminologi al-Qur'an disebut dengan $a l$-' $a z \bar{a} b$. Kemudian jika kita memandangnya dari sudut orang yang beriman maka musibah disana dapat kita artikan sebagai ujian atau pelajaran dari Allah untuk menguji seberapa besar keimanan mereka ketika diberi sebuah ujian atau serentetan ujian, hal ini disitilahkan dengan albala'.

2. Bentuk bencana alam dan cara penanggulangannya

Pada umumnya dijelaskan baik di dalam al-Qur'an atau sains bahwa bencana yang terjadi di dalam ini tidaklah terlepas dari hubungan sebab akibat antara Tuhan, Alam, dan manusia sendiri. Bencana alam yang timbul antara Tuhan dengan Alam adalah sebuah keniscayaan adanya. Karena meskipun antara Tuhan dengan Alam memiliki sifat yang sama-sama Qadim, keduanya memiliki perbedaan yaitu antar Qadim Azali yang dimiliki oleh Tuhan dan 
Qadim Zamani yang dimiliki oleh Alam. Untuk membedakan antar keduanya, bisa saja Tuhan meleburkan alam yang merupakan ciptaannya dengan sebuah bencana sebagai bukti bahwa terdapat perbedaan antara Tuhan dan Alam. Dan dari sinilah penulis menganalisis bahwa terdapat bencana yang tidak ada kaitan ulah manusia di dalamnya, bencana disini mutlak karena hukum dan ketentuan Allah SWT kepada alam ini seperti tsunami. Dapat kita lihat dan pahami bahwa tidak ada manusia yang mampu menciptakan Tsunami, hal ini menandakan bahwa bencana yang seperti ini mutlak hak dan ketentuan dari Allah SWT yang diberikan kepada alam ini. Kalaupun ada peran dari manusia itu terletak pada sebelum atau setelah adanya bencana alam jenis tersebut, dan bagaimana manusia memanfaatkan atau mengolah alam sebelum atau setelah adanya bencana alam.

Contoh peran manusia dalam bencana alam seperti ini dapat dilihat dengan adanya tsunami, manusia hanya berperan bagaimana mengolah alam sesuai tanggung jawabnya sebagai khalifah di muka bumi dengan mengolah alam sebelum tsunami itu terjadi atau bagaimana manusia mengolahnya setelah alam dilanda bencana tsunami tersebut. Berbicara mengenai bencana jenis ini, jelas manusia tidak mempunyai kemampuan untuk menanggulanginya. Sifat yang dapat manusia ambil hanyalah bagaimana menyikapi setelah adanya bencana tersebut. Berikut bentuk dari bencana alam yang merupakan sunnatullah:

a. Gempa bumi. Adalah getaran atau guncangan yang terjadi di permukaan bumi yang disebabkan oleh tumpukan antar lempeng bumi, patahan aktif, aktivitas gunung api, atau runtuhan batuan.

b. Letusan gunung api. Adalah bagian dari aktivitas vulkanik yang dikenal dengan istilah "erupsi”. Bahaya yang dapat ditimbulkan oleh letusan gunung berapi seperti awan panas, lontaran material (pijar), hujan abu lebat, lava, gas beracun, tsunami dan banjir lahar.

c. Tsunami. Adalah serangkaian gelombang laut raksasa yang timbul karena adanya pergeseran di dasar laut akibat gempa bumi. 
d. Angin puting beliung. Adalah angin kencang yang datang secara tiba-tiba, mempunyai pusat, bergerak melingkar menyerupai spiral dengan kecepatan 40-50 km/jam hingga menyentuh permukaan bumi dan akan hilang dalam waktu singkat (3-5 menit).

e. Gelombang pasang. Adalah gelombang tinggi yang ditimbulkan karena efek terjadinya siklon tropis di sekitar wilayah Indonesia dan berpotensi kuat menimbulkan bencana alam. Indonesia bukan daerah lintasan siklon tropis tetapi keberadaan siklon tropis akan memberikan pengaruh kuat terjadinya angin kencang, gelombang tinggi disertai hujan deras.

Dari kelima contoh bencana alam di atas terutama tiga di antaranya jelas tampak bahwa tidak ada ulah tangan manusia yang mempengaruhi terjadinya ketiga bencana alam tersebut. Melainkan terjadinya ketiga bencana alam tersebut saling berkaitan antara satu dengan yang lainnya, dimana letusan gunung berapi dapat memicu adanya pergeseran lempeng bumi akibat getaran dari letusan, kemudian dari getaran tersebut timbullah gempa bumi, dengan adanya gempa bumi maka akan muncul pula bencana yang akan menyusul yaitu tsunami. Tsunami yang mencul akibat gelombang yang dihasilkan dari pergeseran lempeng bumi di bawah lautan.

Setelah adanya bencana alam yang ada hanya terdapat pada hubungan Tuhan dengan Alam. Maka akan terdapat pula bencana alam yang terwujudnya itu melalui hubungan antara alam dan manusia. Bencana yang seperti ini akan muncul dengan adanya pola sebab akibat yang menunjukan bahwa adanya hubungan antara alam dan manusia. Contoh dari bencana alam ini seperti tanah longsor yang disebabkan oleh ulah tangan manusia yang melakukan penebangan pohon secara berlebihan pada alam, sehingga akar-akar pohon yang selama ini dijadikan penahan bagi tanah menjadi lapuk dan menghilang karena pohon telah ditebang yang jelas telah kehilangan kehidupannya di hutan. Berikut akan penulis jelaskan beberapa bencana alam yang terbentuk dari pola sebab akibat yang terjadi antara alam dan manusia. 
a. Tanah longsor. Adalah salah satu jenis gerakan masa tanah atau batuan, ataupun percampuran antara keduanya, menuruni atau keluar lereng akibat terganggunya kestabilan tanah atau batuan penyusun lereng.

b. Banjir. Adalah peristiwa atau keadaan dimana terendamnya suatu daerah atau daratan karena volume air yang meningkat. Contohnya dapat kita lihat pada negara Indonesia. Negara Indonesia adalah negara yang rawaan akan terkena banjir karena berapa di wilayah asia-pasifik, terlebih di Indonesia terdapat musim hujan dimana pada musim ini debit air cendrung meningkat. Sejenak, jika memandang sebatas wilayah dimana indonesia berada, bencana jenis ini terjadi karena pengaruh alam saja. Akan tetapi, perlu kita sadari bahwa penyebab dari banjr dipengaruhi oleh dua faktor, yaitu: pertama, banjir yang disebabkan oleh alam. Contohnya seperti meningkatnya curah hujan, fisiografi, erosi, dan sedimentasi, kapasitas sungai, kapasitas drainase, dan pengaruh air pasang; kedua, Banjir yang disebabkan oleh aktivitas manusia yang berimplikasi pada perubahan-perubahan pada lingkungan seperti rusaknya hutan. ${ }^{20}$ Penulis menganalisa bahwa sikap yang patut manusia lakukan adalah dengan melakukan antisipasi terhadap terjadinya bencana alam. Pengantisipasian dapat dilakukn dengan mengambil maksud umum yang terdapat di dalam al-Qur'an dengan menjaga alam dengan sebaik mungkin.

c. Kekeringan. Adalah ketersediaan air yang jauh di bawah kebutuhan air untuk hidup, pertanian, kegiatan ekonomi dan lingkungan. Adapun yang dimaksud dengan kekeringan dibidang pertanian adalah kekeringan yang terjadi di lahan pertanian yang di dalamnya terdapat tanaman yang sedang dibudidayakan atau dikembangkan.

d. Kebakaran. Adalah situasi dimana bangunan pada suatu tempat seperti rumah/pemukiman, pabrik, pasar, gedung dan lain-lain dilanda api yang menimbulkan korban dan/atau kerugian.

${ }^{20}$ BNPD, jurnal penanggulangan bencana, vol. 4 No. 2, November 2013 
e. Kebakaran hutan. Adalah suatu keadaan di mana hutan dan lahan dilanda api, sehingga mengakibatkan kerusakan hutan dan lahan yang menimbulkan kerugian ekonomis dan atau nilai lingkungan. Kebakaran hutan dan lahan seringkali menyebabkan bencana asap yang dapat mengganggu aktivitas dan kesehatan masyarakat sekitar. Pencegahan yang dapat dilakukan untuk mengurangi efel dari kebakaran hutan adalah dengan menyadari bahwa alam perlu diperlakukan dengan baik. Manusia memang diperintahkan untuk menjadi pengelola di alam, akan tetapi terdapat batsan yang perlu manusia laukan dalam mengolah alam dengan baik. Salah satunya adalah ketika kita hendak mengambil hasil alam maka kita perlu memperhatikan cara yang akan kita lakukan untuk mengambil hasil tersebut. contohnya adalah ketika kita hendak membuka lahan untuk pertanian, alah satu cara yang dapat ditempuh dalam pembukaan lahan disini adalah dengan teknik membakar, teknik membakar adalah salah satu teknik yang digunakan oleh perusahaan untuk meremajakan perkebunan miliknya atau bahkan menambah jumlah lahan yang ada.

Beberapa alasan mengapa teknik membakar diambil adalah: Pertama, cara ini dipandang sangat mudah dan tidak memerlukan biaya yang besar. Kedua, kelebihan dari segi waktu yang tdiak memerlukan waktu lama untuk menunggu tanaman-tanaman yang akan dihilangkan terdekomposisi atau terurai dengan alami. Jika dibakar maka hanya membuthkan waktu beberapa minggu atau beberapa hari tergantung dari luas lahan yang dibakar. Ketiga, pembakaran hutan dimaksudkan untuk menurunkan kualitas lahan yang ada di hutan itu untuk mendapatkan daerah yang dapat dikembangkan menjadi kawasan hutan yang permanen secara legal. Sehingga dengan demikian kualitas tanah yang sudah rendah dapat dimanipulasi sebagai bukan lagi tanah hutan melainkan sebagai tanah perkebunan dan dari sana mereka akan mudah mengklaim bahwa tanah itu adalah milik mereka. Akan tetapi, disamping sisi kepraktisan yang ada terdapat sisi negatif yang ada di dalamnya baik itu akan berpengaruh kerusakan dalam jangka 
pendek atau dalam jangka panjang terhadap alam. Seperti udara yang tercemar oleh asap pembakaran, sumber air yang tak jauh menjadi kotor karena abu yang berterbangan, dan seperti kepulan asap yang menggangu seperti kejadian yang terakhir ini terjadi di wilayah Sumatra.

Dari uraian di atas dapat dipahami bahwa pembukaan lahan pertanian dengan cara membakar hutan dapat menimbukan kerusakan dalam skala besar. Akan tetapi, cara ini dapat dipandang baik apabila terdapat pengawasan dalam pelaksanan operasi ini. Sehingga tidak terjadi kerusakan akibat cara ini dalam skala besar. Beberapa cara untuk mengontrol adalah mengadakan sistem bergilir dalam pembukaan lahan, pembatasan luas lahan yang akan dibuka, dan mengganti alternatif dengan membuka lahan menggunakan alat berat sebagai pengganti dari pembakaran lahan

f. Abrasi. Adalah proses pengikisan pantai oleh tenaga gelombang laut dan arus laut yang bersifat merusak. Abrasi biasanya disebut juga erosi pantai. Kerusakan garis pantai akibat abrasi ini dipicu oleh terganggunya keseimbangan alam daerah pantai tersebut. Walaupun abrasi bisa disebabkan oleh gejala alami, namun manusia sering disebut sebagai penyebab utama abrasi. Karena terdapat ulah manusia yang menyebabkan terganggungan keseimbangan alam disekitar laut seperti terdapatnya ketidak keseimbangan ekositem laut dan pemanasan global, hal ini terjadi karena eksploitasi besarbesaran terhadap kekayaan laut.

Selain adanya bencana alam yang terwujud karena hubungan manusai dengan alam. Terdapat pula bencana alam yang penyebab terjadinya adalah hubugan manusia dengan manusia. Bencana alam jenis ini lebih dikategorikan bencana alam yang jenis psikologis atau yang berkenaan dengan soaial. Berikut beberapa bencana alam psikologis atau sosial:

a. Kecelakaan transportasi. Adalah kecelakaan moda transportasi yang terjadi di darat, laut dan udara. 
b. Kecelakaan industri. Adalah kecelakaan yang disebabkan oleh dua

c. faktor, yaitu perilaku kerja yang berbahaya (unsafe human act) dan kondisi yang berbahaya (unsafe conditions). Adapun jenis kecelakaan yang terjadi sangat bergantung pada macam industrinya, misalnya bahan dan peralatan kerja yang dipergunakan, proses kerja, kondisi tempat kerja, bahkan pekerja yang terlibat di dalamnya.

d. Kejadian luar biasa. Adalah timbulnya atau meningkatnya kejadian kesakitan atau kematian yang bermakna secara epidemiologis pada suatu daerah dalam kurun waktu tertentu. Status Kejadian Luar Biasa diatur oleh Peraturan Menteri Kesehatan RI No. 949/MENKES/SK/VII/2004.

e. Konflik sosial. Adalah suatu gerakan massal yang bersifat merusak tatanan dan tata tertib sosial yang ada, yang dipicu oleh kecemburuan sosial, budaya dan ekonomi yang biasanya dikemas sebagai pertentangan antar suku, agama, ras (SARA).

f. Aksi teror. Adalah aksi yang dilakukan oleh setiap orang yang dengan sengaja menggunakan kekerasan atau ancaman kekerasan sehingga menimbulkan suasana teror atau rasa takut terhadap orang secara meluas atau menimbulkan korban yang bersifat masal, dengan cara merampas kemerdekaan sehingga mengakibatkan hilangnya nyawa dan harta benda, mengakibatkan kerusakan atau kehancuran terhadap obyekobyek vital yang strategis atau lingkungan hidup atau fasilitas publik internasional.

g. Sabotase. Adalah tindakan yang dilakukan untuk melemahkan musuh melalui subversi, penghambatan, pengacauan dan/ atau penghancuran. Dalam perang, istilah ini digunakan untuk mendiskripsikan aktivitas individu atau grup yang tidak berhubungan dengan militer, tetapi dengan spionase. Sabotase dapat dilakukan terhadap beberapa sruktur penting, seperti infrastruktur, struktur ekonomi, dan lain-lain. 


\section{E. Kesimpulan}

Berdasarkan pemahaman ayat al-Qura'an yang menjelaskan bagaimana tanggung jawab manusia sebagai wakil Tuhan di muka bumi ini. Terdapat keharusan manusia dalam menyikapi musibah yang diturunkan dan menghindari perbuatan yang dapat memicu pada diturunkannya musibah itu kepada manusia. Artinya dalam menyikapi berarti manusia harus sadar bahwa terdapat musibah yang kemunculannya itu merupakan sebuah ujian bagi manusia. Sedangkan dalam musibah yang kemunculanya ada kaitannya dengan manusia, maka manusia harus memperhatikan apa yang akan dilakukan karena setiap hal yang dilakukan oleh manusia pastilah Allah SWT akan beri ganjaran terhdapa perbuatan tersebut. dan turunnya musibah terhadap ulah tangan manusia merupakan salah satu ganjaran yang Allah SWT berikan untuk sarana menyadarkan manusia. [] 


\section{DAFTAR PUSTAKA}

BNPD, "Pengetahuan Defenisi Dan Jenis Bencana", dalam http://www.bnpd, go.id/

BNPD, Jurnal Penanggulangan Bencana”. vol. 4 No. 2, 2013.

Fakhri, J. 'Sains Dan Teknologi Dalam Al-Qur'an Dan Impliksinya Dalam Pembelajaran". Dalam Jurnal Ta'dib, Vol. XV No. 01, 2010, h. 122-142.

Ghoffar, A. Tafsir Ibnu Katsir jilid 5, Bogor: Pustaka Imam Syafi'I, 2014.

, Tafsir Ibnu Katsir Jilid 6, Bogor: Pustaka Imam Syafi'I, 2014.

Gk, Tasaro. Muhammad Sang Pewaris Hujan, Yogyakarta: Bentang, 2015.

Khairi, M.R. Tanggung Jawab Terhadap Al-Quran, dalam https://encikriduan.wordpress.com

Misbahkhunur. "Tanggung Jawab Terhadap Alam Dan Lingkungan", modul 8 universitas brawijaya, 221-240

Mustaqimah. "Urgensi Tafsir Kontekstual Dalam Penafsiran alQur'an", Journal IAIN gorontalo vol. 12 no. 1, 2015, h. 138149.

Samidi. "Tuhan, Manusia, Dan Alam: Analisis Kitab Primbon Atassadhur Adammakna", dalam Shahih, Vol. 1, No. 1, 2016. h. $14-26$

Software CD Maktabah Syamilah

Suryadilaga, Muhammad Alfatih, "Pemahaman Hadits Tentang Bencana (Sebuah Kajian Teologis Terhadap Hadits-Hadits Tentang Bencana)", dalam Essensia, Vol. XIV No. 1, 2013, h. $83-102$ , Kontekstualisasi Hadis Dalam Kehidupan Berbangsa Dan Berbudaya, Yogyakarta: Kalam, 2017. 